\title{
D-limonene in diabetic rats
}

\author{
Shahrokh Bagheri ${ }^{1,2}{ }^{\circledR}$, Mostafa Moradi Sarabi $^{3}{ }^{\circledR}$, Mohammadreza Gholami $^{{ }^{\circledR}}$, Vahideh Assadollahi ${ }^{\left.{ }^{(}\right)}$, \\ Reza Mohammadrezaei Khorramabadi ${ }^{\mathbb{D}}$, Forouzan Hadipour Moradi ${ }^{1}$, Hassan Ahmadvand ${ }^{*}{ }^{\mathbb{D}}$ \\ ${ }^{1}$ Razi Herbal Medicines Research Center, Lorestan University of Medical Sciences, Khorramabad, Iran \\ ${ }^{2}$ Student Research Committee, Lorestan University of Medical Sciences, Khorramabad, Iran \\ ${ }^{3}$ Department of Biochemistry and Genetics, Faculty of Medicine, Lorestan University of Medical Sciences, Khorramabad, Iran \\ ${ }^{4}$ Medical Technology Research Center, Institute of Health Technology, Kermanshah University of Medical Sciences, Kermanshah, Iran \\ ${ }^{5}$ Cancer and Immunology Research Center, Research Institute for Health Development, Kurdistan University of Medical Sciences, \\ Sanandaj, Iran
}

\section{A R T I C L E IN F O}

\section{Article Type:}

Original

\section{Article History:}

Received: 10 August 2020

Accepted: 4 December 2020

Published online: 23 January 2021

Keywords:

Diabetes

Limonene

Oxidative stress

Antioxidant enzymes

Gene expression

\begin{abstract}
A B S T R A C T
Introduction: Diabetes mellitus (DM) is a multi-factorial condition associated with oxidative stress. Limonene, as a plant-derived antioxidant, can be used for treating DM. Objectives: An investigation on antioxidant effects in diabetic rats exposed to D-limonene. Materials and Methods: Sixty male Wistar rats were categorized into six groups as follows: control (healthy rats), diabetic control (untreated diabetic rats), sham glibenclamide, diabetic glibenclamide, sham limonene, and finally diabetic limonene. Alloxan $(100 \mathrm{mg} / \mathrm{dL})$ was infused intraperitoneally to induce type 1 diabetes in rats. Rats in certain groups were given limonene $(100 \mathrm{mg} / \mathrm{dL})$ and glibenclamide $(10 \mathrm{mg} / \mathrm{dL})$ orally for 8 weeks. Subsequently, animals were killed, and their kidneys were removed. Serum levels of biochemical factors (including serum creatinine, urea, and glucose) were determined, and factors such as nitric oxide (NO), malondialdehyde (MDA), glutathione (GSH), and myeloperoxidase (MPO) were measured in kidney tissue homogenate. The gene expression and enzymatic activity of glutathione peroxidase (GPx), catalase (CAT), and superoxide dismutase (SOD) in the kidney were measured by real-time polymerase chain reaction (real-time PCR) and spectrophotometry, respectively.

Results: Limonene treatment significantly decreased serum glucose, creatinine, and urea. Additionally, MDA, MPO, and NO significantly decreased while GSH increased after treatment with limonene. Real-time RT-PCR showed significant elevation $(\mathrm{P}<0.05)$ in mRNA levels of GPx, CAT, and SOD in the limonene-treated compared with the diabetic control group.

Conclusion: Our results demonstrated that limonene as an herbal antioxidant had better effects on antioxidant markers compared to glibenclamide in rat models of diabetes.
\end{abstract}

\section{Implication for health policy/practice/research/medical education:}

Our study exhibited that D-limonene could ameliorate serum glucose, creatinine, urea, the activities of antioxidant enzymes (GPx, CAT and SOD), the levels of MDA, GSH, NO, and MDA activity in the diabetic treated group.

Please cite this paper as: Bagheri S, Moradi Sarabi M, Gholami M, Assadollahi V, Mohammadrezaei Khorramabadi R, Hadipour Moradi F, Ahmadvand H. D-limonene in diabetic rats. J Renal Inj Prev. 2021; 10(3): e24. doi: 10.34172/jrip.2021.24.

\section{Introduction}

Diabetes mellitus (DM) is a big challenge of the health care system and as a global outbreak has affected many people all over the world. Different types of diabetes have been recognized, among which insulin-dependent $\mathrm{DM}$, gestational DM, and noninsulin-dependent DM have gained more attention. The most recent statistics indicate an increasing trend in the ratio of patients with diabetes, which is expected to reach 592 million by 2035 . Hyperglycemia is the most important feature of diabetes. Many reasons have been reported for the development of DM, including the lack of production and malfunction of insulin. Among the main challenges of this disease are its long-term complications that affect the body's vital organs from the cardiovascular and nervous systems to kidneys and eyes (1). 
Oxidative stress is a major contributor to the pathogenesis of various disorders including cardiovascular diseases, diabetes and cancer. A large and key part of oxidative stress comes from reactive oxygen species (ROS) which are among major and important free radicals. It has been reported that high blood glucose level is an important factor contributing to the generation of ROS in diabetes. Biomolecules are the main targets damaged by free radicals. Therefore, different types of antioxidants including natural ones derived from plants can be good choices for eliminating free radicals and treating diabetes (2).

There are different types of anti-diabetic drugs that reduce blood sugar by certain mechanisms. One of the most important of these is glibenclamide - a secondgeneration agent that belongs to the second-generation orally consumed sulfonylurea derivatives. These drugs enter pancreatic beta cells and bind to the sulfonylurea receptor 1 (SUR1), which blocks the $\mathrm{K}^{+}$- ATPase channel and reduces potassium flow into the cell, depolarizing the membrane. As the membrane is depolarized, calcium channels are opened allowing the entry of this ion into the cell. Increased intracellular calcium concentration activates signaling proteins that control the contraction of microtubules and microfilaments and the release of insulin exocytosis granules (3). However, these drugs have high costs and significant side effects. On the other hand, the number of people with diabetes is increasing, and this disease continues to affect patients for the rest of their lives. Therefore, finding alternatives to these drugs is of particular importance (4).

The use of herbal sources with antioxidant effects returns to ancient times. Today, it is documented that the active ingredients of plants have a wide range of antioxidant properties. D-limonene (4-isopropenyl-1methylcyclohexene) is a colorlessliquid and water-insoluble member of the cyclic monoterpenes family. Because of its fragrant lemon smell and solubility, D-limonene is frequently used for preparing fragrant materials. It is found in more than 300 plant species and essential oils. Some of these plant species include fennel, celery, yerba mate, citrus fruits, apple, money tree, savory, thyme, cherry, pistachios, pine, pepper, pear, bushy matgrass, mint and fir. The US Food and Drug Administration (FDA) has listed limonene under the "Generally Safe Accepted (GRAS)" category of biological compounds. A series of biological properties including antioxidant and chemo-preventive effects have been described for limonene. Moreover, the compound has been reported to play therapeutic roles in a variety of diseases associated with oxidative stress (for example cancer, diabetes, infections, inflammation, allergy, asthma, metabolic syndrome, etc.) (5). Studies on Drosophila model of Alzheimer's disease (AD) showed a neuroprotective effect for limonene against the A $\beta 42$ induced neurotoxicity, highlighting its therapeutic potential in $\mathrm{AD}$ partly through reducing apoptosis, ROS production, and inflammation in cerebral neurons (6). Kumar et al showed that D-limonene delayed diabetic cataracts in rat models by inhibiting aldose reductase (7).

\section{Objectives}

The role of D-limonene in regulating antioxidant mediators in diabetes is unclear. Thus, we investigated the antioxidant effects of D-limonene in rats with alloxaninduced (type 1) DM.

\section{Materials and Methods \\ Chemicals}

D-Limonene was purchased from Sigma (USA), and ELISA kits were prepared from Pars Azmoon Co. (Iran). Thiobarbituric acid (TBA), trichloroacetic acid (TCA), Tris-EDTA, dinitrothiocyanobenzene (DTNB), phosphate buffer saline (PBS), and O-dianisidine were from Merck (Germany).

\section{Design and grouping}

Sixty male Wistar rats (200-220 g) were kept in appropriate laboratory condition $\left(22^{\circ} \mathrm{C}, 12\right.$-hour light/ dark cycle) for one week to adaptation. During this period, they received standard food and water. The animals were randomly assigned to six groups $(n=10$ per group). Groups 1 and 2 included healthy and diabetic rats that received no treatment. In group 3, healthy rats were fed with $10 \mathrm{mg} / \mathrm{kg}$ glibenclamide (sham glibenclamide). In group 4 (diabetic glibenclamide), diabetic rats were treated with glibenclamide (oral, $10 \mathrm{mg} / \mathrm{kg}$ ). In group 5 (sham limonene), healthy rats were fed with $\mathrm{D}$-limonene $(100 \mathrm{mg} / \mathrm{kg})$. Finally, diabetic rats in group 6 received oral D-limonene $(100 \mathrm{mg} / \mathrm{kg})$. All the treatments were conducted for 8 weeks.

Type 1 diabetes was induced via the intraperitoneally injection of alloxan monohydrate $(100 \mathrm{mg} / \mathrm{kg})$. At the end of the 8-week period, the rats were anesthetized using ketamine and diazepam. The heart was directly punctured to collect $5 \mathrm{~mL}$ blood, which was then used for separating serum. Additionally, kidneys were removed for further examination. Only two serum and kidney samples were used for experiments. The blood samples were placed in the laboratory for 2 hours and allowed to form a clot before being centrifuged (10 minutes, $3000 \mathrm{rpm}$ ). Next, serum samples were collected into microtubes. Specific ELISA kits were purchased from Pars Azmoon Co. (Tehran, Iran) to determine the intended biochemical factors using a BT3000 AutoAnalyzer (Italy). After being removed by surgery, kidneys were also obtained and kept at $-80^{\circ} \mathrm{C}$ until further analysis.

\section{Serum glucose, urea, and creatinine measurement} These parameters were measured using specific Pars Azmoon ELISA Kits and an auto-analyzer apparatus (BT 
3000, Biotecnica Instruments SpA, Rome, Italy).

\section{Malondialdehyde (MDA) measurement}

Renal MDA level in all the groups was measured in accordance with our previous study (8). First, $0.06 \%$ TBA $(1.5 \mathrm{~mL})$ and $1 \%$ TCA $(1 \mathrm{~mL})$ were added to the sample $(100 \mu \mathrm{L})$ and incubated at $100^{\circ} \mathrm{C}$ (30 minutes). The samples were allowed to cool and then centrifuged at $1000 \mathrm{rpm}$ (15 minutes). The supernatant was isolated and using a spectrophotometer, its absorbance was recorded versus blank at $535 \mathrm{~nm}$ to determine MDA level as $\mu \mathrm{mol} /$ mg protein. The experiment was performed in triplicate for all the samples.

\section{Glutathione (GSH) measurement}

In order to GSH assessment based on the relevant protocol (8), we performed firstly $0.2 \mathrm{M}$ Tris-EDTA $(\mathrm{pH}=8)(140$ $\mu \mathrm{L})$, the sample $(25 \mu \mathrm{L})$, and $0.1 \mathrm{M} \mathrm{DTNB}(30 \mu \mathrm{L})$ were poured into an ELISA microplate. Then, the absorbance of the sample versus blank was recorded at $412 \mathrm{~nm}$ by an ELISA reader to determine GSH concentration as $\mu \mathrm{mol} /$ mg upon three replications.

\section{Myeloperoxidase (MPO) measurement}

MPO activity was measured in accordance with the method described by Dhiman, $M$. For this, $0.1 \mathrm{M}$ potassium phosphate buffer $(\mathrm{pH}=6)(0.3 \mathrm{~mL}), 0.01 \mathrm{M}$ hydrogen peroxide $(0.03 \mathrm{~mL})$, and $0.02 \mathrm{M} \mathrm{O}$-dianisidine $(0.5 \mathrm{~mL})$ along with the sample $(10 \mu \mathrm{L})$ were mixed in a tube. The sample used for this experiment was either homogenized kidney tissue or serum. Change in the absorbance of sample at $460 \mathrm{~nm}$ during a 10-minute period was finally determined $\left(\varepsilon=11300 \mathrm{M}^{-1} \mathrm{~cm}^{-1}\right)$, and MPO activity was expressed as unit/mg.

\section{NO measurement}

Serum NO was determined in accordance with the previous study (8). The serum sample $(50 \mu \mathrm{L})$ was mixed in a microplate with the grace reagent $(100 \mathrm{~mL})$ containing $\mathrm{N}$-1-aminoethyl naphthylamine dihydrochloride $1 \%$ in phosphoric acid 5\% and sulfanilamide $1 \%$. The mixture was incubated at room temperature before recording its absorbance at $540 \mathrm{~nm}$. A standard curve plotted based on sodium nitrate $\left(\mathrm{NaNO}_{2}=0-110 \mu \mathrm{mol} / \mathrm{L}\right)$ was applied for determining NO concentration.

\section{Catalase (CAT)}

With introducing slight modifications, a method described in our previous study was used to determine CAT activity (8). Briefly, potassium phosphate $(\mathrm{pH}=8,50$ $\mathrm{mM}, 1 \mathrm{~mL})$ was added to the sample $(50 \mu \mathrm{L})$ before the addition of $50 \mu \mathrm{L} \mathrm{H}_{2} \mathrm{O}_{2}$. Absorbance at $240 \mathrm{~nm}$ was read using a spectrophotometer at 0,30 , and 60 seconds after the addition of $\mathrm{H}_{2} \mathrm{O}_{2}$. The experiment was conducted in triplicate for all samples, and CAT activity was recorded as $\mathrm{U} / \mathrm{mg}$ protein.

\section{Glutathione peroxidase (GPX)}

This parameter was measured in accordance with the method described in previous study with slight modifications (8). At first, Tris- $\mathrm{HCl}(\mathrm{pH}=7,0.4 \mathrm{~m}, 200$ $\mu \mathrm{L})$, NaN3 $(1 \mathrm{mM}, 100 \mu \mathrm{L})$, sample $(200 \mu \mathrm{L})$, glutathione (GSH) $(2 \mathrm{mM}, 200 \mu \mathrm{L})$, and $\mathrm{H}_{2} \mathrm{O}_{2}(0.2 \mathrm{mM}, 100 \mu \mathrm{L})$ were consecutively mixed with each other in a tube and incubated at $37^{\circ} \mathrm{C}$ (10 minutes). After that, $10 \%$ TCA $(0.4 \mathrm{~mL})$ was added, and the mixture was centrifuged (3 minutes, $2000 \mathrm{rpm}$ ) to separate the supernatant which was transferred into an ELISA microplate. Subsequently, Tris-EDTA $(\mathrm{pH}=8,0.2 \mathrm{mM}, 140 \mu \mathrm{L})$ and DTNB (30 $\mu \mathrm{L}$ ) were added to the microplate, and the mixture was incubated $\left(25^{\circ} \mathrm{C}\right)$ for 30 minutes. Applying an ELISA reader, the samples' absorption was finally read at $420 \mathrm{~nm}$ versus blank. The experiment was conducted in triplicate for each sample, and GPx activity was expressed as U/mg protein.

\section{Superoxide dismutase (SOD)}

For homogenization, phosphate buffer $(\mathrm{pH}=8.8,50$ $\mathrm{mM}$ ) was added to $100 \mathrm{mg}$ of renal tissue on ice. After centrifugation ( $5724 \mathrm{~g}, 4^{\circ} \mathrm{C}, 5$ minutes), the supernatant was separated and kept at $-20^{\circ} \mathrm{C}$. SOD activity (expressed as $\mathrm{U} / \mathrm{mL}$ ) was determined according to the method described by Mark Lund in 1974. In contact with EDTA, the rate of pyrogallol autoxidation at $\mathrm{pH} 2.8$ is $50 \%$. This method is based on the competition of SOD and molecular oxygen to neutralize or oxidize pyrogallol, respectively. Each unit of SOD activity corresponds to the enzymatic activity required to produce a $50 \%$ oxidation inhibitory effect (8).

After adjusting the spectrophotometer using Tris-EDTA buffer $(\mathrm{pH}=2.8), 1000 \mu \mathrm{L}$ of this buffer along with distilled water $(50 \mu \mathrm{L})$ and $0.2 \mathrm{M}$ pyrogallol $(1000 \mu \mathrm{L})$ were poured into a cuvette to determine the absorbance of the mixture at 0 and 60 -second time points. The difference between the absorption of the mixture at these two time points was designated as control. For the experimental samples, $50 \mu \mathrm{L}$ serum was used instead of distilled water, and its absorption was determined in the same way. Finally, the following formula was utilized to calculate the inhibitory effect of SOD on pyrogallol oxidation as percentage:

Inhibition of pyrogallol autoxidation $(\%)=$

Test absorbance at zero - Test absorbance at one minute Control absorbance at zero - Control absorbance at one minute SOD activity as $\mathrm{U} / \mathrm{ml}$ was calculated as:

SOD activity $(\mathrm{U} / \mathrm{mg}$ protein $)=$

Inhibition of pyrogallol auto - autoxidation (\%) $50 \%$

Gene expression analysis

The gene expression of intended anti-oxidative enzymes 
was determined using quantitative real-time polymerase chain reaction (real-time PCR). TriPure RNA isolation reagent (Roche Applied Science, Germany) was used to extract total RNA from kidney tissue. The integrity of the purified RNA was assessed by electrophoresis on $2 \%$ formaldehyde denaturing $2 \%$ agarose gel. The extracted RNA was then stored at $-80^{\circ} \mathrm{C}$ for cDNA synthesis. Applying oligo dT primers, $\mathrm{M}-\mathrm{MuLV}$ reverse transcriptase (MBI Fermentas, Lithuania), and the extracted RNA $(2.0 \mu \mathrm{g})$, cDNA was synthesized. Using specific primers (Table 1), the gene expression of SOD, GPx, and CAT was determined by GAPDH as a reference. The experiment was conducted in triplicate on a Corbett Rotor-Gene 6000 (Qiagen, Germany) instrument. The sequences of the primers were those used in a previous study (8).

\section{Ethics issues}

This experimental protocol was carried out according to the guidelines of the research ethics committee of Iranian ethical guidelines for the use of animals in research. Additionally, all animal experiments were in accordance with protocols approved by the United States National Institutes of Health (NIH, 1978). Rats were used in research according to the guidelines of the Ethics Committee of Lorestan University of Medical Sciences. This study was extracted from Ph.D thesis of Shahrokh Bagheri at this university (Thesis \# 2035).

\section{Statistical analysis}

Statistical analyses were conducted in SPSS 22 software. Mean \pm SEM was used to describe quantitative variables. The comparison of data between groups was carried out by one-way analysis of variance (ANOVA) followed by the Bonferroni test. Statistical significance was regarded at $P<$ 0.05 . Gene expression data was analyzed using GraphPad Prism software (version 6.01) .

\section{Results}

Changes in serum creatinine, glucose, and urea in limonene treated rats

In comparison with control diabetic rats $(442.25 \pm 45.97748$ $\mathrm{mg} / \mathrm{dL})$, serum level of glucose significantly declined in the diabetic rats received limonene $(148.67 \pm 17.60303$ $\mathrm{mg} / \mathrm{dL}, P<0.05)$ and glibenclamide $(390.00 \pm 38.77177$ $\mathrm{mg} / \mathrm{dL}$ ); however, the decline in the recent group was not as much as in the diabetic limonene group (Table 2).

Furthermore, serum urea level significantly elevated in the diabetic control respective to healthy control rats. In the diabetic limonene group, a significant reduction in serum urea respective to the diabetic control $(47.3333 \pm 2.33809$ $\mathrm{mg} / \mathrm{dL}$ versus $72.0000 \pm 26.19160 \mathrm{mg} / \mathrm{dL}$ ) was detected. In contrast, serum urea showed no remarkable fluctuation in the diabetic rats treated with glibenclamide in comparison with the control diabetic animals (Table 2).

Serum creatinine increased in untreated diabetic rats compared to healthy counterparts; however, treating diabetic rats with limonene induced a reduction in serum creatinine compared with the control diabetic animals $(0.6000 \pm 0.10000$ versus $0.8375 \pm 0.10607 \mathrm{mg} / \mathrm{dL}$, $P<0.05)$. No significant change was observed comparing the diabetic rats treated with glibenclamide compared to control diabetic rats (Table 2).

\section{Effect of limonene on renal MDA}

Renal MDA is frequently used as a marker of lipid peroxidation. There was a significant rise in this marker in the diabetic compared with healthy control rats $(96.1316 \pm 31.42336 \mu \mathrm{mol} / \mathrm{mg}$ protein versus $43.7661 \pm 3.73695 \mu \mathrm{mol} / \mathrm{mg}$ protein). On the other hand, limonene treatment significantly decreased serum MDA as compared with control diabetic rats $(69.9244 \pm 3.92029$ $\mu \mathrm{mol} / \mathrm{mg}$ protein versus $96.1316 \pm 31.42336, \mu \mathrm{mol} / \mathrm{mg}$ protein, $P<0.05)$. Moreover, renal MDA level showed a significant reduction in the diabetic rats treated with glibenclamide in comparison with control diabetic animals $(50.8209 \pm 11.15563 \mu \mathrm{mol} / \mathrm{mg}$ protein versus $96.1316 \pm 31.42336 \mu \mathrm{mol} / \mathrm{mg}$ protein; Table 3).

\section{Effect of limonene on serum GSH}

Renal GSH level ( $\mu \mathrm{mol} / \mathrm{mg}$ protein) was significantly lower in the control diabetic than healthy rats. Nevertheless, this parameter increased significantly in the diabetic rats treated with limonene $(5.9450 \pm 2.07761 \mu \mathrm{mol} / \mathrm{mg}$ protein versus $2.5700 \pm 0.40453 \mu \mathrm{mol} / \mathrm{mg}$ protein) but insignificantly in the rats received glibenclamide $(3.9053 \pm 0.59022 \mu \mathrm{mol} /$ $\mathrm{mg}$ protein versus $2.5700 \pm 0.40453 \mu \mathrm{mol} / \mathrm{mg}$ protein, Table 3).

\section{Effect of limonene on kidney MPO level}

There was an increase in the activity of MPO in the diabetic untreated rats in comparison with healthy

Table 1. Primers' sequence used for quantitative RT-PCR

\begin{tabular}{llll}
\hline Gene & Forward primer & Reverse primer & Product size (bp) \\
\hline CAT & 5'- ATTGCCGTCCGATTCTCC -3' & 5'- CCAGTTACCATCTTCAGTGTAG -3' \\
SOD & 5'- CGAGCATGGGTTCCATGTC -3' & 5'- CTG GACCGCCATGTTTCTTAG - 3' \\
GPX & 5' - CAGTTCGGACATCAGGAGAAT -3' & 5'-AGAGCGGGTGAGCCTTCT -3' & 101 \\
GAPDH & 5'-ATGGAGAAGGCTGGGGCTCACCT -3' & 5'-AGCCCTTCCACGATGCCAAAGTTGT -3' & 139 \\
\hline
\end{tabular}


Table 2. Effects of limonene on different biochemical parameters in the serum of rats

\begin{tabular}{|c|c|c|c|c|c|c|c|c|}
\hline \multirow[t]{2}{*}{ Parameter } & \multicolumn{6}{|c|}{ Treatment } & \multirow{2}{*}{ SE } & \multirow{2}{*}{$P$ value } \\
\hline & Control & Diabetic control & Sham glibenclamide & Diabetic glibenclamide & Sham limonene & Diabetic limonene & & \\
\hline $\mathrm{GLU}(\mathrm{mg} / \mathrm{dL})$ & $152.00 \pm 15.48117^{d}$ & $442.25 \pm 45.97748^{a}$ & $143.44 \pm 24.15632^{\mathrm{d}}$ & $390.00 \pm 38.77177^{b}$ & $252.86 \pm 93.44415^{c}$ & $148.67 \pm 17.60303^{d}$ & 19.45009 & $<0.0001$ \\
\hline UREA (mg/dL) & $41.8571 \pm 4.98092^{b}$ & $72.0000 \pm 26.19160^{\mathrm{a}}$ & $44.8889 \pm 6.66041^{b}$ & $68.3333 \pm 11.51086^{\mathrm{a}}$ & $44.1429 \pm 10.00714^{b}$ & $47.3333 \pm 2.33809^{b}$ & 2.61552 & $<0.0001$ \\
\hline $\mathrm{CR}(\mathrm{mg} / \mathrm{dL})$ & $0.7200 \pm 0.07257^{b}$ & $0.8375 \pm 0.10607^{a}$ & $0.7933 \pm 0.07263^{\mathrm{ab}}$ & $0.8567 \pm 0.09165^{\mathrm{a}}$ & $0.7000 \pm 0.11547^{b}$ & $0.6000 \pm 0.10000^{c}$ & 0.01804 & $<0.0001$ \\
\hline
\end{tabular}

The different letters written in the form of a superscript $(a, b, c, d)$ represent a significant difference between treatments of each row, $P<0.05$

Note: GLU, glucose; CR, creatinine.

Table 3. Effects of limonene on different biochemical parameters in the kidney level of rats

\begin{tabular}{|c|c|c|c|c|c|c|c|c|}
\hline \multirow[t]{2}{*}{ Parameter } & \multicolumn{6}{|c|}{ Treatment } & \multirow{2}{*}{ SE } & \multirow{2}{*}{$P$ value } \\
\hline & Control & Diabetic control & Sham glibenclamide & Diabetic glibenclamide & Sham limonene & Diabetic limonene & & \\
\hline $\begin{array}{l}\text { MDA ( } \mu \mathrm{mol} / \\
\text { mg protein) }\end{array}$ & $69.9244 \pm 3.92029^{b}$ & $45.8470 \pm 3.73863^{c}$ & $50.8209 \pm 11.15563^{c}$ & $43.7094 \pm 6.13831^{c}$ & $96.1316 \pm 31.42336^{a}$ & $43.7661 \pm 3.73695^{c}$ & 3.69516 & $<0.0001$ \\
\hline $\begin{array}{l}\text { GSH ( } \mu \text { mol/ } \\
\text { mg protein) }\end{array}$ & $5.9450 \pm 2.07761^{\mathrm{ab}}$ & $4.0688 \pm 0.96549^{c d}$ & $3.9053 \pm 0.59022^{\text {cd }}$ & $5.1323 \pm 1.01415^{\text {bc }}$ & $2.5700 \pm 0.40453^{d}$ & $7.0529 \pm 1.59903^{\mathrm{a}}$ & 0.30067 & $<0.0001$ \\
\hline $\begin{array}{l}\text { MPO (U/ } \\
\text { mg protein) }\end{array}$ & $70.4009 \pm 3.93104^{b}$ & $52.2494 \pm 3.21516^{c}$ & $47.0005 \pm 8.39278^{c}$ & $25.5830 \pm 4.13319^{d}$ & $85.9729 \pm 6.31008^{\mathrm{a}}$ & $27.8113 \pm 3.38736^{d}$ & 3.71072 & $<0.0001$ \\
\hline $\begin{array}{l}\text { NO ( } \mu \text { mol/ } \\
\text { mg protein) }\end{array}$ & $30.3704 \pm 9.42020^{b}$ & $29.4974 \pm 2.96518^{b}$ & $29.0388 \pm 8.51544^{b}$ & $28.8713 \pm 3.10914^{b}$ & $41.6931 \pm 9.60325^{\mathrm{a}}$ & $29.0079 \pm 3.12230^{b}$ & 1.13395 & $<0.01$ \\
\hline $\begin{array}{l}\text { CAT (nmol } \\
\text { /mg protein) }\end{array}$ & $19.1233 \pm 4.09822^{b}$ & $26.5627 \pm 2.55412^{\mathrm{a}}$ & $18.7824 \pm 2.95687^{b}$ & $15.5097 \pm 2.86129^{c}$ & $13.6629 \pm 1.93803^{c}$ & $18.7025 \pm 2.6658^{b}$ & 0.69167 & $<0.0001$ \\
\hline $\begin{array}{l}\mathrm{GPX} \text { ( U/mg } \\
\text { protein) }\end{array}$ & $16.3032 \pm 4.21516^{\mathrm{b}}$ & $16.4621 \pm 2.96767^{b}$ & $27.3635 \pm 3.07434^{b}$ & $21.6108 \pm 5.33687^{\mathrm{a}}$ & $11.6652 \pm 2.20504^{c}$ & $16.3889 \pm 2.10411^{b}$ & 0.71748 & 0.001 \\
\hline $\begin{array}{l}\text { SOD ( U/mg } \\
\text { protein) }\end{array}$ & $4.9962 \pm 0.91784^{\mathrm{a}}$ & $4.7967 \pm 0.72073^{a}$ & $1.8836 \pm 0.46971^{b}$ & $2.4283 \pm 0.54105^{b}$ & $0.7823 \pm 0.67964^{c}$ & $2.4105 \pm 0.4626^{\mathrm{ab}}$ & 0.27685 & $<0.0001$ \\
\hline
\end{tabular}

The different letters written in the form of a superscript $(a, b, c, d)$ represent a significant difference between treatments of each row, $P<0.05$

Note: MDA, malondialdehyde; GSH, glutathione; MPO, myeloperoxidase; NO, nitric oxide; CAT, catalase; GPX, glutathione peroxidase; SOD, superoxide dismutase.

animals. Treatment with limonene reduced MPO activity as compared with the diabetic control group $(70.4009 \pm 3.93104$ unit/mg protein versus $85.9729 \pm 6.31008 \mathrm{unit} / \mathrm{mg}$ protein, $P<0.05)$. Moreover, renal MPO activity showed a significant reduction in the diabetic rats treated with glibenclamide in comparison with untreated diabetic rats $(47.0005 \pm 8.39278 \mathrm{U} / \mathrm{mg}$ protein versus $85.9729 \pm 6.31008 \mathrm{U} / \mathrm{mg}$ protein, Table 3 ).

\section{Effect of limonene on kidney NO level}

An increased level of $\mathrm{NO}(\mu \mathrm{mol} / \mathrm{mg}$ protein) was observed in diabetic compared to healthy control rats. Furthermore, in the diabetic limonene group, there was a decrease in renal NO as compared with the control diabetic group $(30.3704 \pm 9.42020 \mu \mathrm{mol} / \mathrm{mg}$ protein versus $41.6931 \pm 9.60325 \mu \mathrm{mol} / \mathrm{mg}$ protein, $P<0.05)$. Moreover, a significant decline in renal NO was observed in the diabetic rats treated with glibenclamide respective to untreated diabetic animals $(29.0388 \pm 8.51544 \mu \mathrm{mol} /$ $\mathrm{mg}$ protein versus $41.6931 \pm 9.60325 \mu \mathrm{mol} / \mathrm{mg}$ protein, Table 3).

\section{Effect of limonene on renal CAT activity}

Renal CAT activity decreased in untreated diabetic rats in comparison with healthy counterparts. However, limonene treatment increased CAT activity [nmol (per minutes)/ mg protein] in the kidney as compared with the diabetic control group $(19.1233 \pm 4.09822 \mathrm{nmol} / \mathrm{mg}$ protein versus $13.6629 \pm 1.93803 \mathrm{nmol} / \mathrm{mg}$ protein, $P<0.05)$. Similarly, significant elevation was seen in renal CAT activity in the diabetic rats fed with glibenclamide compared with untreated diabetic animals (18.7824 $\pm 2.95687 \mathrm{nmol} /$ $\mathrm{mg}$ protein versus $13.6629 \pm 1.93803 \mathrm{nmol} / \mathrm{mg}$ protein, Table 3).

\section{Effect of limonene on renal GPx activity}

Renal GPx activity decreased in untreated diabetic in comparison with healthy control rats. In comparison, limonene treatment boosted renal GPx activity (U/ $\mathrm{mg}$ protein) compared to the diabetic control group $(16.3032 \pm 4.21516 \mathrm{U} / \mathrm{mg}$ protein versus $11.6652 \pm 2.20504$ $\mathrm{U} / \mathrm{mg}$ protein, $P<0.05)$. A significant increase in renal GPx activity was also seen in the diabetic rats receiving glibenclamide compared to untreated diabetic animals $(27.3635 \pm 3.07434 \mathrm{U} / \mathrm{mg}$ protein versus $11.6652 \pm 2.20504$ $\mathrm{U} / \mathrm{mg}$ protein, Table 3 ).

\section{Effect of limonene on renal SOD}

There was a decrease in renal SOD in control diabetic in comparison with healthy rats. Limonene treatment 
increased renal SOD (U/mg protein) activity compared to the untreated diabetic group $(4.9962 \pm 0.91784 \mathrm{U} / \mathrm{mg}$ protein versus $0.7823 \pm 0.67964 \mathrm{U} / \mathrm{mg}$ protein, $P<0.05)$. Furthermore, renal SOD activity significantly increased in the diabetic rats fed with glibenclamide compared with untreated diabetic rats $(1.8836 \pm 0.46971 \mathrm{U} / \mathrm{mg}$ protein versus $0.7823 \pm 0.67964 \mathrm{U} / \mathrm{mg}$ protein), but this elevation was lower than the one observed in the diabetic limonene group (Table 3 ).

\section{Renal gene expression of anti-oxidative enzymes}

The gene expression of CAT (8.03-fold), GPx (4.77fold), and SOD (4.73-fold) significantly elevated in the rats treated with limonene in comparison with untreated diabetic rats (Figure 1, $P<0.05$ ). Similar to limonenetreated rats, our results also showed that the genes' expression increased in healthy and diabetic rats fed with glibenclamide (9.10, 9.98, and 5.55-fold, respectively).

\section{Discussion}

Diabetes affects different organs of the body mostly via inducing oxidative stress. Because of their safety, phytochemical compounds are increasingly being used for treating different diseases. Natural antioxidants such as limonene are beneficial in mitigating oxidative stress in such diseases. Limonene is a monoterpene found in a variety of plants showing anti-diabetic effects because of the presence of this compound. Various studies have indicated that limonene plays a central role in reducing diabetes related sequelae (e.g. nephropathy, cataracts, etc). Moreover, limonene strongly inhibits protein glycation (9). The results of our research showed that limonene treatment significantly reduced serum glucose, urea, and creatinine, as well as renal MDA, MPO, and NO. On the other hand, renal GSH, GPx, CAT, and SOD levels were significantly increased following limonene treatment. Similarly, feeding diabetic rats with glibenclamide significantly attenuated oxidative markers and boosted antioxidant enzymes.

Previous researchers have documented that limonene can modulate oxidative stress through different pathways. One of these pathways is the inhibition of protein unfolding and ensuing biological events. Limonene could also affect the mitogen-activated protein kinase pathway which plays a role in promoting apoptosis via inducing oxidative stress. It has been shown that limonene increases the gene expression of GLUT1 and therefore can prevent hyperglycemia-induced oxidative stress and tissue damage. On the other hand, limonene has been involved in elevated activity of the enzymes of the gluconeogenic pathway (fructose 1, 6-bisphosphatase and glucose 6-phosphatase) and the decreased activity of glucokinase and glycolytic enzymes. A role has also been noted for limonene in modulating the synthesis of glycogen in hepatocytes (10).

Treatment of diabetic rats with limonene significantly reduced serum levels of glucose, urea, and creatinine. Hyperglycemia, a diagnostic hallmark of diabetes, was shown to be attenuated by limonene. In various prior studies, it has been documented that D-limonene has hypoglycemic activity which is associated with its antioxidant properties, particularly in citrus fruits (11). In accordance, another similar study indicated that limonene treatment reduced plasma glucose level (12). The reduction of plasma glucose level following treatment with limonene was also confirmed by another study (13). It was also shown that the combination of linalool and limonene could reduce blood glucose level in diabetic rats (14). The hypoglycemic effects of Carum carvi which is a limonene rich (40-60\%) plant have been attributed to the presence of this compound (15). Moreover, limonene can affect the insulin secretion ability of pancreatic $\beta$ cells (12). As well, limonene in combination with linalool reduced serum creatinine and blood urea nitrogen (BUN) levels in diabetic rats (14). In addition, the hypoglycemic and antiglycation effects of Aegle marmelos have been

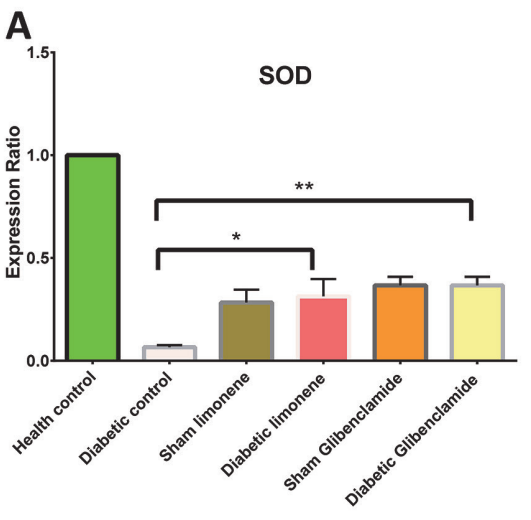

Groups
B

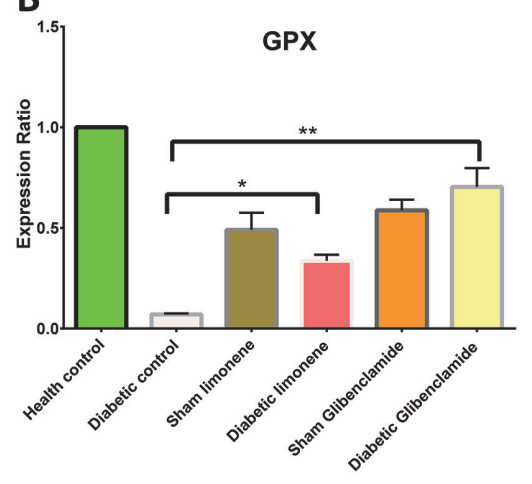

Groups
C

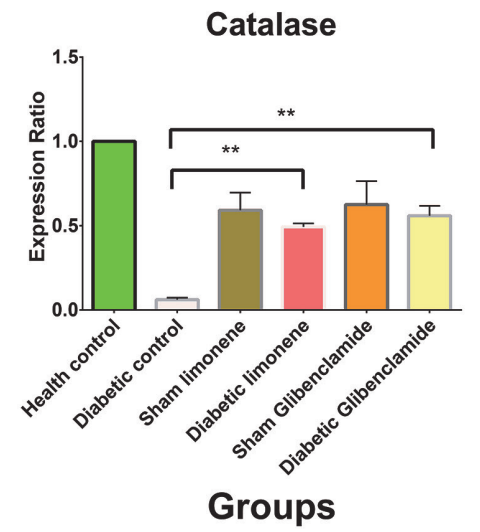

Figure 1. Relative expression of SOD, GPx, and CAT genes in kidney tissue of rates fed with limonene and glibenclamide: (A) GPx, (B) CAT and (C) SOD. Bars marked with asterisk are significantly different as verified by Bonferroni Test $\left({ }^{*} P<0.05,{ }^{* *} P<0.01\right)$. 
attributed to the presence of limonene. The recent plant has also been able to protect the kidney from diabetesinduced damage as evidenced by decreased levels of serum BUN and creatinine (9). Other plants including onion, garlic, and chard have had such effects on serum glucose, urea, and creatinine levels (16).

Our results also demonstrated that MPO and NO levels decreased significantly in diabetic rats after limonene treatment. MPO is an index for assessing inflammation and is expressed in polymorphonuclear leukocytes. The anti-inflammatory effects of limonene have been proven in different studies. Limonene was shown to reduce the inflammation caused by acute lung injury (evidenced by decreased level of MPO). Moreover, there is a lot of evidence confirming the anti-inflammatory effects of limonene and its ability to reduce MPO (17).

We also demonstrated that serum MDA level significantly declined in limonene-treated rats. MDA increased significantly after the induction of diabetes, reflecting the damage to cell membranes. It has been documented in different studies that limonene is a potent antioxidant that can be used for treating diabetes. A similar study conducted on the effects of limonene on diabetes-induced lipid peroxidation (13) showed that limonene effectively normalized the serum level of MDA. This property of D-limonene may be related to its free radical scavenging activity. Moreover, it was reported that the combination of limonene and linalool reduced MDA level in diabetic rats (14). Other studies on a series of compounds such as soy protein and genistein indicated their significant roles in reducing MDA level (18). GSH level also significantly raised in the diabetic rats exposed to limonene. GSH is an essential mediator in regulating the antioxidant status of the body. In line, limonene was able to increase GSH level in the liver and induce the formation of disulfide bonds in proteins (13). Moreover, our results demonstrated that the activity of antioxidant enzymes (GPx, CAT, and SOD) was significantly higher in limonene-treated than untreated rats, which was in line with the antioxidant effects of Bacopa monnieri, a limonene-rich plant, evidenced by increased levels of renal GPx, CAT, and SOD (19). Furthermore, it has been shown that limonene treatment can boost SOD, CAT, and GPx levels in diabetic rats (13). In addition, it has been reported that the combination of linalool and limonene enhances SOD, CAT, and GPx levels in diabetic animal models (14).

In the present study, gene expression analysis in harmony with biochemical assessments revealed the up-regulation of the assessed antioxidant enzymes in limonene-treated groups. Likewise, resveratrol was shown to promote its anti-oxidative effects via modulating SOD activity (20). Another study that assessed the effects of garlic on cardiac oxidative stress induced by diabetes showed that garlic enhanced the expression of SOD (21). In parallel, our results showed the antioxidant effects of limonene in animal models of diabetes, suggesting its therapeutic potential in this condition.

\section{Conclusion}

Taking together, regarding its antioxidant, limonene is proposed as a safe herbal therapeutic agent, particularly in diabetes. In our study, we compared the effects of glibenclamide, as a standard drug for diabetes treatment, with those of limonene as a natural antioxidant. Regarding the widespread side effects of anti-diabetes chemical drugs, it is better to replace these drugs with natural antioxidants. The widespread plant sources of limonene provide the opportunity to exploit this active ingredient in medical applications.

\section{Limitations of the study}

Lack of financial resources to more accurately investigate the antioxidant effect of limonene through signaling pathways associated with antioxidant enzymes was the most important limitation of the present study.

\section{Acknowledgments}

The authors gratefully acknowledge Department of Clinical Biochemistry, Faculty of Medicine, Lorestan University of Medical Sciences for technical support.

\section{Authors' contribution}

HA and designed the project. SB, PK and FHM collected the data. SV analyzed the data. RMRK and VA wrote the manuscript. MMS and MG revised the English version and edited the final draft. All authors participated in preparing the final draft of the manuscript, revised the manuscript and critically evaluated the intellectual contents. All authors have read and approved the content of the manuscript and confirmed the accuracy or integrity of any part of the work.

\section{Conflicts of interest}

The authors declare that they have no competing interests.

\section{Ethical considerations}

Ethical issues (including plagiarism, data fabrication, double publication) have been completely observed by the authors.

\section{Funding/Support}

The present investigation was financially supported by the Lorestan University of Medical Sciences, Khorramabad, Iran (Proposal Thesis No: 94/7 and Ph.D. Thesis No: 2035).

\section{References}

1. Salem MB, Kolsi RBA, Dhouibi R, Ksouda K, Charfi S, Yaich M, et al. Protective effects of Cynara scolymus leaves extract on metabolic disorders and oxidative stress in alloxan-diabetic rats. BMC Complement Altern Med. 
2017;17(1):328. doi: 10.1186/s12906-017-1835-8.

2. Huynh K, Bernardo BC, McMullen JR, Ritchie RH. Diabetic cardiomyopathy: mechanisms and new treatment strategies targeting antioxidant signaling pathways. Pharmacol Ther. 2014;142:375-415. doi: 10.1016/j.pharmthera.2014.01.003.

3. Rorsman $\mathrm{P}$, Renström E. Insulin granule dynamics in pancreatic beta cells. Diabetologia. 2003;46:1029-45. doi: 10.1007/s00125-003-1153-1.

4. Thent ZC, Abd Latiff A. Savior of diabetes: Antioxidants. Diabetes Food Plan. IntechOpen; 2018.doi: 10.5772/ intechopen.71748.

5. Sun J. D-Limonene: safety and clinical applications. Altern Med Rev. 2007;12(3):259

6. Shin M, Liu QF, Choi B, Shin C, Lee B, Yuan C, et al. Neuroprotective effects of limonene $(+)$ against $\mathrm{A} \beta 42-$ induced neurotoxicity in a Drosophila model of Alzheimer's disease. Biol Pharm Bull. 2020;43:409-17. doi: 10.1248/bpb. b19-00495.

7. Kumar MP, Mamidala E, Al-Ghanim K, Al-Misned F, Ahmed Z, Mahboob S. Effects of D-Limonene on aldose reductase and protein glycation in diabetic rats. Journal of King Saud University - Science. 2020;32:1953-8. doi: 10.1016/j.jksus.2020.01.043.

8. Lateef A, Hassan SK, Rashid S, Ali N, Zeeshan M, Sultana S. D-limonene suppresses doxorubicin-induced oxidative stress and inflammation via repression of COX-2, iNOS, and NFiB in kidneys of Wistar rats. Exp Biol Med. 2014;239:465-76. doi: 10.1177/1535370213520112.

9. Panaskar SN, Joglekar MM, Taklikar SS, Haldavnekar VS, Arvindekar AU. A egle marmelos C orrea leaf extract prevents secondary complications in streptozotocininduced diabetic rats and demonstration of limonene as a potent antiglycating agent. J Pharm Pharmacol. 2013;65(6):884-94. doi: 10.1111/jphp.12044.

10. Habtemariam S. Antidiabetic potential of monoterpenes: A case of small molecules punching above their weight. Int J Mol Sci. 2018;19:4. doi: 10.3390/ijms19010004.

11. Jing L, Zhang Y, Fan S, Gu M, Guan Y, Lu X, et al. Preventive and ameliorating effects of citrus D-limonene on dyslipidemia and hyperglycemia in mice with high-fat diet-induced obesity. Eur J Pharmacol. 2013;715:46-55. doi: 10.1016/j.ejphar.2013.06.022.

12. Murali R, Saravanan R. Antidiabetic effect of d-limonene, a monoterpene in streptozotocin-induced diabetic rats. Biomed Prev Nutr. 2012;2(4):269-75. doi: 10.1016/j. bionut.2012.08.008.

13. Murali R, Karthikeyan A, Saravanan R. Protective effects of D-limonene on lipid peroxidation and antioxidant enzymes in streptozotocin-induced diabetic rats. Basic Clin Pharmacol Toxicol. 2013;112(3):175-81. doi: 10.1111/ bcpt. 12010 .

14. More TA, Kulkarni BR, Nalawade ML, Arvindekar AU. Antidiabetic activity of linalool and limonene in streptozotocin-induced diabetic rat: a combinatorial therapy approach. Int J Pharm Pharm Sci. 2014;6:159-63.

15. Pandeya SN, Kumar R, Kumar A, Pathak AK. Antidiabetics Review on Natural Products. Research Journal of Pharmacy and Technology. 2010;3:300-18.

16. Lee S-K, Hwang J-Y, Kang M-J, Kim Y-M, Jung S-H, Lee $\mathrm{J}-\mathrm{H}$, et al. Hypoglycemic effect of onion skin extract in animal models of diabetes mellitus. Food Sci Biotechnol. 2008;17:130-4.doi: I410-ECN-0101-2013-573-001010067.

17. de Almeida AAC, Silva RO, Nicolau LAD, de Brito TV, de Sousa DP, dos Reis Barbosa AL, et al. Physiopharmacological investigations about the antiinflammatory and antinociceptive efficacy of (+)-limonene epoxide. Inflammation. 2017;40:511-22.doi: 10.1007/ s10753-016-0496-y.

18. Polkowski K, Mazurek AP. Biological properties of genistein. A review of in vitro and in vivo data. Acta Pol Pharm. 2000;57:135-55.

19. Kapoor R, Srivastava S, Kakkar P. Bacopa monnieri modulates antioxidant responses in brain and kidney of diabetic rats. Environ Toxicol Pharmacol. 2009;27:62-9. doi: $\quad$ 10.1016/j.etap.2008.08.007.

20. Spanier G, Xu H, Xia N, Tobias S, Deng S, Wojnowski L, et al. Resveratrol reduces endothelial oxidative stress by modulating the gene expression of superoxide dismutase 1 (SOD1), glutathione peroxidase $1(\mathrm{GPx} 1)$ and NADPH oxidase subunit (Nox4). J Physiol Pharmacol. 2009;60:1116.

21. Padiya R, Chowdhury D, Borkar R, Srinivas R, Bhadra MP, Banerjee SK. Garlic attenuates cardiac oxidative stress via activation of PI3K/AKT/Nrf2-Keap1 pathway in fructosefed diabetic rat. PloS one. d 2014;9:e94228.oi: 10.1371/ journal.pone.0094228.

Copyright (C) 2021 The Author(s); Published by Nickan Research Institute. This is an open-access article distributed under the terms of the Creative Commons Attribution License (http://creativecommons.org/licenses/by/4.0), which permits unrestricted use, distribution, and reproduction in any medium, provided the original work is properly cited. 